\title{
Antimicrobial activity of a crude peptide extract from lablab bean (Dolichos lablab) for semi-dried rice noodles shelf-life
}

\author{
Shitapan Bai-Ngew ${ }^{1}$, Treethip Chuensun ${ }^{1}$, Sutee Wangtueai ${ }^{2}$, Suphat Phongthai ${ }^{1}$, Kittisak Jantanasakulwong ${ }^{1,4}$, \\ Pornchai Rachtanapun ${ }^{1,4}$, Vinyoo Sakdatorn ${ }^{1}$, Warinporn Klunklin ${ }^{1}$, Joe M. Regenstein ${ }^{3}$, Yuthana Phimolsiripol ${ }^{1,4 *}$ \\ ${ }^{1}$ Faculty of Agro-Industry, Chiang Mai University, Chiang Mai 50100, Thailand; ${ }^{2}$ College of Maritime Studies and \\ Management, Chiang Mai University, Samuth Sakorn, 74000 Thailand; ${ }^{3}$ Department of Food Science, Cornell University, \\ Ithaca, New York,14853-7201, USA; ${ }^{4}$ Center of Excellence in Materials Science and Technology, Chiang Mai University, \\ Chiang Mai 50200, Thailand
}

*Corresponding author: Y. Phimolsiripol, Faculty of Agro-Industry, Chiang Mai University, Chiang Mai 50100, Thailand. Email: yuthana.p@cmu.ac.th

Submitted: 20 January 2021; Accepted: 27 February 2021; Published: 21 April 2021

(c) 2021 Codon Publications

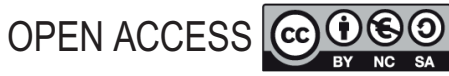

RESEARCH ARTICLE

\begin{abstract}
This study provides an application of new, natural source of crude peptide extract from Lablab bean (CPL). Use of additive such as benzoate in the rice noodle industry is a common practice and has several beneficial effects on quality and shelf-life. However, the shelf-life of semi-dried rice noodles can be extended by crude peptide extract with acceptable quality when compared to other additives. This research aimed to extract CPL and determine its effect on the growth of microorganisms. The use of the CPL to extend the shelf-life of semi-dried rice noodles was compared with other natural extracts (chitosan and thymol) and benzoic acid. The CPL samples were extracted using $5 \%$ pepsin and incubated for up to $24 \mathrm{~h}$. CPL at $200 \mathrm{mg} / \mathrm{mL}$ could be used as the growth inhibitor for Bacillus cereus but not for Staphylococcus aureus and Escherichia coli. It was found that noodles with CPL had the highest cooking loss (4.69) and lowest tensile strength (22.6 g.force). Overall-liking scores showed slightly liked (6.0 out of 9 ) and $68 \%$ of the consumers accepted the CPL-treated noodles. Shelf-life testing showed that CPL could extend the shelf-life of the noodles for 3 days than the control (1 day). Using $200 \mathrm{mg} / \mathrm{mL}$ of CPL could extend the shelf-life more than 3 times when compared to the control noodle (no additive). The CPL was nearly as effective as benzoic acid that could be kept for 3 days. Hedonic score in overall-liking showed a slightly like (6.2) for the noodles with CPL. This study suggests the application of adding CPL could be used as new natural additive and seems to be promising to apply in many food products such as pasta or sausages.
\end{abstract}

Keywords: antimicrobial activity; Dolichos lablab; lablab bean; rice noodles; shelf-life

\section{Introduction}

Rice noodles are the second most consumed food in Thailand (Saikhunthod and Peerattana, 2015). However, fresh and semi-dried rice noodles have a short shelf-life. With high moisture content (37\%), semi-dried rice noodles can be stored for only 1-2 days before microbial spoilage. More than $80 \%$ of spoilage is caused by microorganisms such as mold, yeast and bacteria (BertholdPluta et al., 2019; Zhang et al., 2016). To extend the shelf-life, preservatives and chemicals such as benzoic or sorbic acid or calcium propionate have been used (Wang et al., 2018). However, when high amounts of preservative and chemicals are consumed, liver and kidney functions are reduced (Inetianbor et al., 2015). Therefore, Codex (2009) limits the use of benzoic acid in noodles to $<1000 \mathrm{mg} / \mathrm{kg}$. According to the Thai Ministry of Public Health, a consumer weighing approximately $50 \mathrm{~kg}$ should not ingest more than $250 \mathrm{mg} / \mathrm{kg}$ body weight of benzoic acid following the Codex advisory specification for the identity and purity of food additives (Ministry of Public Health, 2016). The use of 
50-100 g of cooked noodles for one meal with maximum benzoic acid use is equivalent to $226-451 \mathrm{mg}$ of benzoic acid per day. The daily dose of benzoic acid should not exceed $2000 \mathrm{mg}$. With the problems mentioned above, natural extracts such as chitosan, thymol, grape seeds, and lemon extracts have been used to extend the shelflife of pasta (Li et al., 2014). Again, Zhang et al. (2020) also found that bamboo leaf extract can be used as a shelf-life extension ingredient. Peptide extracts have been shown to inhibit both Gram-positive bacteria and Gram-negative bacteria (Gasu et al., 2018). Such microbial inhibited peptides have been extracted from some types of beans. It has been reported that peptides with the four amino acids, namely, leucine, valine, methionine, and serine, can be used to inhibit Gram-positive microorganisms (Tsutsumi and Tsutsumi, 2014). For example, Wong and $\mathrm{Ng}$ (2005) studied the peptides from lima beans and groundnuts, and used them to inhibit Mycobacterium phlei, Bacillus megaterium, Bacillus subtilis, and Proteus vulgaris. The concentrations need for a $50 \%$ reduction $\left(\mathrm{IC}_{50}\right)$ were $96,115,98$, and $81 \mu \mathrm{M}$, respectively, with lima beans and $87,105,98$ and $75 \mu \mathrm{M}$, respectively, with groundnut.

Lablab bean (Dolichos lablab) is commonly grown in areas of Southeast Asia as it has a high nutrient content and is an inexpensive source of protein (Borijindakul and Phimolsiripol, 2013; Jaisankar and Manivannan, 2018). Lablab beans typically have $24.9-26.5 \%$ protein with a good balance of essential amino acids such as lysine, histidine, etc. Some published data have shown small antimicrobial and antifungal effects. Seeds of the lablab bean contain lectin proteins, which have significant antimicrobial activity on different bacterial strains such as Vibrio mimicus, S. aureus, B. cereus, Salmonella typhi, and Shigella dysentery (Rahman and Akhter, 2018; Saha et al., 2014). El-Araby et al. (2020) also found that bean lectins showed antimicrobial activity against $S$. aureus and Pseudomonas aeruginosa. However, the information on lablab bean extract and application in the shelf-life of noodles is very poor. Therefore, this research aimed to extract crude peptides from lablab beans (CPL) and determine the ability to inhibit microorganisms in semidried rice noodles compared to two natural materials (chitosan and thymol) and chemical preservative (benzoic acid). The qualities of noodles, including physical, chemical, microbial, and sensory properties, were investigated in the production and shelf-life testing.

\section{Materials and Methods}

\section{Materials}

Dried lablab beans (Dolichos lablab L.) were purchased from Mae-Sot District, Tak Province, Thailand. Chemical compositions of lablab bean including moisture (AOAC 950.46), protein (AOAC 976.06), fat (AOAC 960.39), ash (AOAC 942.05), crude fiber (AOAC 962.09), and carbohydrate were measured following the standard methods of AOAC (2007). Pepsin enzyme (porcine gastric (EC 3.4.23.1), Merck, Darmstadt, Germany) was used in this study. The cultures of B. cereus, S. Aureus, and E. coli were purchased from the Thailand Institute of Scientific and Technological Research (TISTR) culture collection (Bangkok, Thailand). Rice flour (Jade Leaf brand, Bangkok Inter Food Co., Ltd., Bangkok, Thailand) and tapioca starch (Fish brand, ETC International Trading Co., Ltd., Bangkok, Thailand) were used for rice noodle preparation. Benzoic acid (Lobachemie PVT Ltd., Mumbai, India), chitosan (King Crab Chitosan Oligomer Type 100 mesh pass, Taming Enterprises, Samutsakon, Thailand) and thymol (Lobachemie PVT Ltd., Mumbai, India) were used as commercially available preservatives.

\section{Crude peptide preparation}

A factorial experiment was used to study three enzyme concentration levels $(1,3$, and $5 \%(\mathrm{w} / \mathrm{v})$ of the protein content in the lablab beans), which corresponded to 4.65 , 14.0, and $23.36 \mathrm{U} / \mathrm{g}$ according to the method of Wang et al. (2007), and three hydrolysis times $(0.5,6$, and $12 \mathrm{~h})$. Hydrochloric acid $37 \%$ with water ( $\mathrm{pH} 2$ ) was added to ground lablab beans $(1: 10 \mathrm{w} / \mathrm{v})$. Then, the samples were incubated in a water bath at $37^{\circ} \mathrm{C}$ for $0.5,6$, and $12 \mathrm{~h}$. The reaction was stopped by heating to $75^{\circ} \mathrm{C}$ for $10 \mathrm{~min}$. Then, it was centrifuged (Universal 320R, Hettich, Westphalia, Germany) at $11,700 \times g$ at $4^{\circ} \mathrm{C}$ for $15 \mathrm{~min}$. After that, the supernatant was dried in a hot air oven at $40^{\circ} \mathrm{C}$ for $6 \mathrm{~h}$ (Cheison et al., 2012). The dried CPL was stored in a desiccator before use.

\section{Molecular weight of protein in CPL}

Sodium dodecyl sulfate polyacrylamide gel electrophoresis (SDS-PAGE) was done by preparing 6-8\% acrylamide gels (Ramos et al., 2019). The samples or the standard proteins were prepared by mixing the sample to buffer at the ratio of 3:1. The buffer contains $0.2 \mathrm{M}$ Tris- $\mathrm{HCl}, \mathrm{pH} 6.8,8$ mM EDTA, $40 \%$ glycerol, $4 \%$ SDS, and $0.4 \%$ bromophenol blue. For reducing conditions, $1 \% \beta$-mercaptoethanol was added and boiled for $2 \mathrm{~min}$. The sample solution and the standard solution were placed in each of the channels. The electrophoresis buffer was 0.025 M Tris-0.192 M glycine and $0.1 \%$ SDS at $\mathrm{pH}$ 8.3. Then, turn on the electric current at 130 Volts for $1.5 \mathrm{~h}$ until the color of bromophenol blue moved to the bottom of the gel. Then, the gel was dyed. Size of protein was identified as a color band relative to the reference color band. 


\section{Minimum inhibitory concentration}

Minimum inhibitory concentration (MIC) was measured using the method of Vipra et al. (2013) and Surin et al. (2018). The CPL was dissolved in $200 \mathrm{mg} / \mathrm{mL}$ distilled water and then mixed using a vortex mixer (G560E, Scientific Industries, New York, USA) for $30 \mathrm{~min}$ and centrifuged at $5,530 \times g$ at $4^{\circ} \mathrm{C}$ for $15 \mathrm{~min}$. Then, the samples were serially diluted twofold serial to $25,50,100$, and $200 \mathrm{mg} / \mathrm{mL}$ with nutrient broth (NB) (MM244, HiMedia Laboratories Pvt. Ltd., Mumbai, India). The samples were incubated at $37^{\circ} \mathrm{C}$ for $24 \mathrm{~h}$. Next, $1 \mathrm{~mL}$ of the sample was added to $50 \mathrm{~mL}$ Trypticase Soy Broth (LQ508, HiMedia Laboratories Pvt. Ltd., Mumbai, India) and incubated at $37^{\circ} \mathrm{C}$ by shaking for $3 \mathrm{~h}$. One $\mathrm{mL}$ of the sample was pipetted into $0.85 \%$ sodium chloride and the turbidity was adjusted to 0.5 McFarland units which equate with bacteria $1.5 \times 10^{8} \mathrm{CFU} / \mathrm{mL}$. The control tubes had distilled water and a mixture of distilled water and NB. The samples were incubated at $37^{\circ} \mathrm{C}$ for $24 \mathrm{~h}$. The result was read by observing the turbidity in each tube and comparing them with the control by comparison to the turbidity measurement paper.

\section{Effect of addition CPL on rice noodle properties}

\section{Noodle preparation}

A completely randomized design (CRD) was used to study the effect of the additives on noodle properties. Four types of additives were studied including chitosan $(1 \% \mathrm{v} / \mathrm{v}$ in lactic acid solution) at $2000 \mathrm{mg} / \mathrm{kg}$ of noodle, thymol $(50 \% \mathrm{v} / \mathrm{v})$ at $2000 \mathrm{mg} / \mathrm{kg}$ of noodles, benzoic acid at $1000 \mathrm{mg} / \mathrm{kg}$ of noodle, and CPL at $200 \mathrm{mg} / \mathrm{mL}$. Noodle preparation used the method of Liu et al. (2014) with slight modification. The ingredients including $125 \mathrm{~g}$ of rice flour, $24 \mathrm{~g}$ of tapioca starch, and $282 \mathrm{~g}$ of water were mixed in a bowl to prepare noodle slurry. The additives were then added to the noodle slurry. About $70 \mathrm{~g}$ of slurry was spread evenly on a stainless-steel tray, size $6 \times 9$ inch, and steamed in a steamer for $3 \mathrm{~min}$ to form a noodle sheet. After that, the noodle sheet was dried at $35^{\circ} \mathrm{C}$ for $10 \mathrm{~min}$, and then cut into strips of $1 \mathrm{~cm}$ width before drying at $60^{\circ} \mathrm{C}$ for $10 \mathrm{~min}$ to obtain semi-dried rice noodles.

\section{Quality measurement of semi-dried rice noodles}

CIE $\mathrm{L}^{*}, \mathrm{a}^{*}$, and $\mathrm{b}^{*}$ of the uncooked and cooked noodles were measured using a Chroma meter (CR-410, KonicaMinolta, Osaka, Japan). The cooking time, cooking loss, and water absorption of noodle were measured according to AACC standard methods 66-50 (AACC International, 2010). Sensory properties of cooked noodle from different additives were evaluated using a 9-point hedonic scale with 1 , dislike extremely, and 9, extremely like the semi-dried rice noodles with crude peptide extract from lablab bean using the method described by Phimolsiripol et al. (2017) and Wangtueai et al. (2020). A total of 50 panelists participated in individual booths in this study which, was held in the Chiang Mai University Sensory Research Unit (Chiang Mai, Thailand). For shelf-life testing, the noodle samples were kept at $30^{\circ} \mathrm{C}$ and tested every day for up to 6 days. Microbial properties, including total plate count, and yeasts and molds, were determined following the methods of AOAC (2007) (methods 999.11 and 997.02 respectively).

\section{Statistical analysis}

One-way analysis of variance (ANOVA) was applied to analyze the data $(P<0.05)$. Duncan's multiple range test (DMRT) was used for post hoc multiple comparisons. The experiments were done in triplicates.

\section{Results and Discussion}

\section{Chemical properties of lablab bean}

Chemical compositions of lablab bean including moisture, fat, ash, crude fiber, and carbohydrate were 10.8, $0.6,3.5,0.2$ and $61.5 \%$, respectively. Lablab bean had 23.26\% protein. Likewise, Borijindakul and Phimolsiripol (2013) reported that protein content in lablab bean was $20-25 \%$. This agrees with another study including $20-25 \%$ crude protein in Dolichos lablab seed (Hossain et al., 2016; Kala et al., 2010). It was found that the main five components of the amino acids in lablab bean were lysine, phenylalanine, leucine, histidine, and tyrosine as listed in Table 1. For CPL, the main five components of amino acid were glutamic acid, lysine, phenylalanine, leucine, and tyrosine. Table 1 shows that $100 \mathrm{~g}$ of CPL had $2642 \mathrm{mg}$ of lysine and $949 \mathrm{mg}$ of histidine. According to the amount of the amino acids found in CPL, it can be expected that the peptide can possibly inhibit microorganisms. This was due to these essential amino acids having cations that enhance their ability to resist microorganisms (Cantor et al., 2019). Intorasoot (2013) also indicated that amino acids that can inhibit microorganisms are the positively charged amino acids, lysine and histidine. The mechanisms of the antimicrobial activity of amino acids were confirmed by Saha et al. (2014). Almost all microorganisms express surface-exposed carbohydrates, which may be covalently bound. Every surface-exposed carbohydrate is a potential lectin-reactive site, giving lectins the ability to form complexes with microbial glycoconjugates.

\section{Protein molecular weight of CPL}

SDS-PAGE showed that the CPL had molecular weight ranging from $30-45 \mathrm{kDa}$ (Figure 1). This was consistent 
Table 1. Amino acid profiles found in the lablab bean and CPL.

\begin{tabular}{lcc} 
Amino acids & $\begin{array}{c}\text { Lablab bean } \\
\text { (mg/100 g) }\end{array}$ & $\begin{array}{c}\text { CPL } \\
\text { (mg/100 g) }\end{array}$ \\
\hline Lysine & 5278 & 2642 \\
Phenylalanine & 3860 & 2178 \\
Leucine & 2927 & 1801 \\
Histidine & 2256 & 949 \\
Tyrosine & 1759 & 1421 \\
Isoleucine & 1578 & 752 \\
Glutamic acid + Glutamine & 1342 & 2979 \\
Valine & 858 & 739 \\
Aspartic acid + Asparagine & 574 & 856 \\
Proline & 393 & 431 \\
Alanine & 332 & 572 \\
Glycine & 309 & 431 \\
Tryptophan & 226 & 152 \\
Serine & 153 & 181 \\
Methionine & 137 & 212 \\
Threonine & 124 & 173 \\
Cysteine & 116 & 131 \\
Arginine & $<5$ & $<5$ \\
\hline
\end{tabular}

with the results of Sukamto et al. (2019) who reported that the range of protein in lablab bean has a molecular weight between 25 and $41 \mathrm{kDa}$, while Saha et al. (2014) found that the molecular weight of hydrolyzed lablab seeds ranged from 18 to $45 \mathrm{kDa}$. From the results of SDSPAGE, all tested samples were found to have the same patterns of proteins. Thus, $5 \%$ pepsin enzyme with $0.5 \mathrm{~h}$ of hydrolysis time was chosen to be used in further shelflife experiments in rice noodles due to lower cost of production and time saving.

\section{Minimum inhibitory concentration}

MIC is measured the lowest concentration completely inhibited the bacterial growth as widely used for determining the antimicrobial properties. (Laokuldilok et al., 2017). It was found that the CPL could inhibit the growth of the microorganisms. The concentration of $200 \mathrm{mg} /$ $\mathrm{mL}$ of the CPL was found to be able to stop the growth of B. cereus as presented in Table 2. Saha et al. (2014) also found that the crude extract from lablab seeds inhibited the growth of B. cereus. El-Araby et al. (2020) confirmed that leguminous seed lectins provided antibacterial and antifungal activities. This is probably due to the exchanges of cations and anions between amino acid and cell membrane, and it causes damage to the cell walls of the microorganisms and stops their growth (Lei et al., 2019). In addition, the cell structure of B. Cereus, which is a Gram-positive bacteria, is less complex than that of gram-negative bacteria (Dia et al., 2014; Reshmi et al., 2012). However, the CPL cannot inhibit the growth of $S$. aureus because $S$. aureus is resistant to adverse conditions (Patel et al., 2012). Moreover, some species of $S$. aureus can produce mucilage-like capsules that are resistant to antibiotics (Arciola et al., 2019; Kuipers et al., 2016). For E. coli, it was also found that the CPL could not stop the growth of E. coli. It is because $E$. coli is a Gram-negative bacteria, which has more complex cell walls than gram-positive bacteria. Gram-positive bacteria have only a single lipid membrane that is surrounded by a thick layer of peptidoglycan. In contrast, gram-negative bacteria have an inner and outer membrane, so antimicrobials cannot penetrate the bacterial membrane in order to exert their effects (Kuipers et al., 2016). Rahman and Akhter (2018) also confirmed that the presence of the outer membrane of Gram-negative bacteria acts as

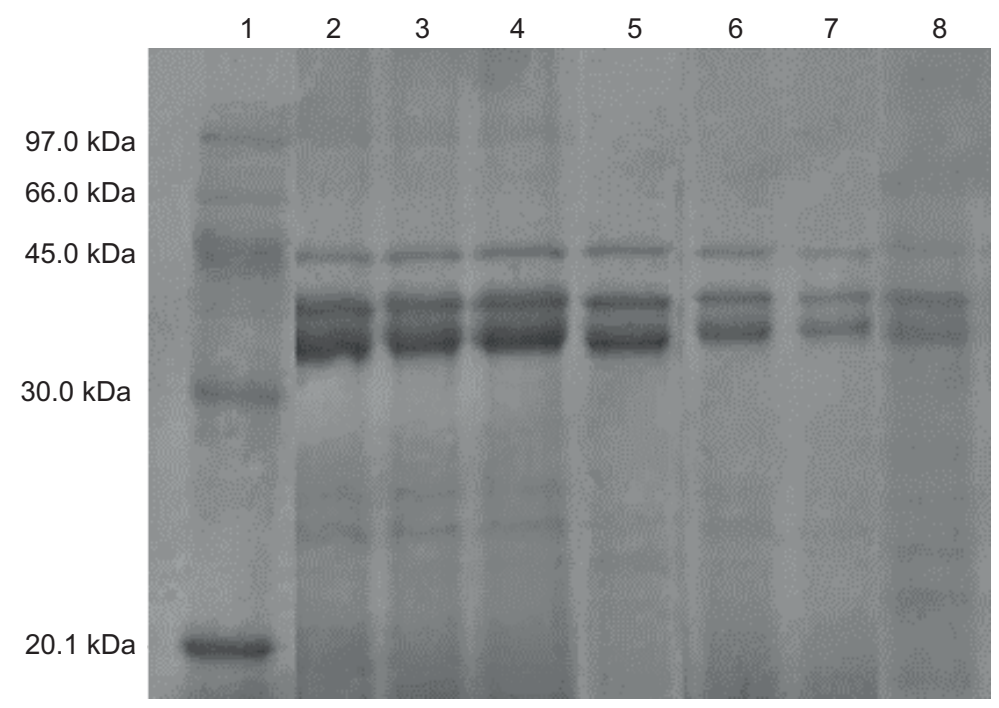

Figure 1. Molecular weights of the CPL: $1=$ References; $2=5 \%$ hydrolysis, $12 \mathrm{~h} ; 3=3 \%$ hydrolysis, $12 \mathrm{~h} ; 4=1 \%$ hydrolysis, $12 \mathrm{~h} ; 5=5 \%$ hydrolysis, $6 \mathrm{~h} ; 6=3 \%$ hydrolysis, $6 \mathrm{~h} ; 7=1 \%$ hydrolysis, $6 \mathrm{~h}$; and $8=5 \%$ hydrolysis, $0.5 \mathrm{~h}$. 
a barrier against numerous antibiotic molecules and the enzymes of the periplasmic spaces. Ratnayani et al. (2017) indicated that protein hydrolysates from beans had no antimicrobial effects on $E$. coli and $S$. aureus. This is because protein hydrolysates are mixtures of different types of amino acids and are of different sizes. As mentioned by Mirzapour-Kouhdasht et al. (2020), peptide concentration is an important factor in the biological and functional properties of the hydrolyzed protein. However, the bioactive peptides should have molecular weight of $<3 \mathrm{kDa}$ for exhibiting antimicrobial activities. Moreover, it was possible that the function of the enzyme inappropriately cut the peptide bond. In other words, the ends of the peptide chains are not positively charged, so they cannot inhibit the growth of the microorganisms. As positive charge facilitates the initial association of CPL with the negatively charged cell membranes, their hydrophobicity allows subsequent insertion of peptide into the hydrophobic cores of the cell membrane, resulting in membrane rupture and cell lysis (Wang and Vermerris, 2016). These findings correspond to the results of Duangmal and Saetongtae (2014) who found that longer duration of protein hydrolysis by enzymes led to inappropriate bond cutting of protein, resulting in less effectiveness of anti-microorganisms (Guinane et al., 2015).

Table 2. Minimum inhibitory concentration of CPL from different hydrolysis conditions.

\begin{tabular}{|c|c|c|c|c|}
\hline \multirow[t]{2}{*}{$\begin{array}{l}\text { Hydrolysis } \\
\text { time (h) }\end{array}$} & \multirow{2}{*}{$\begin{array}{l}\text { Enzyme } \\
\text { concentration } \\
(\%)\end{array}$} & \multicolumn{3}{|c|}{$\begin{array}{l}\text { Minimum inhibitory concentration } \\
\text { (MIC) }(\mathrm{mg} / \mathrm{mL})\end{array}$} \\
\hline & & B. cereus & S. aureus & E. coli \\
\hline \multirow[t]{3}{*}{0.5} & 1 & - & - & - \\
\hline & 3 & - & - & - \\
\hline & 5 & 200 & - & - \\
\hline \multirow[t]{3}{*}{6} & 1 & 200 & - & - \\
\hline & 3 & 200 & - & - \\
\hline & 5 & 200 & - & - \\
\hline \multirow[t]{3}{*}{12} & 1 & 200 & - & - \\
\hline & 3 & 200 & - & - \\
\hline & 5 & 200 & - & - \\
\hline
\end{tabular}

\section{Color and cooking quality of semi-dried rice noodles}

The appearance characteristics of the noodles with different additives were shown in Figure 2. The lightness $\left(\mathrm{L}^{*}\right.$ value) of the cooked noodle was in the range of 65.5-70.6, which was equivalent to standard noodles with $L^{*}$ values between 60 and 80 (Chung et al., 2012). The noodle of CPL had the highest $\mathrm{a}^{*}$ value (redness) and $\mathrm{b}^{*}$ value (yellowness), which is shown in yellow shades (Figure 2c). For cooking loss, the noodle with CPL had the highest cooking loss which was $4.69 \%$, while the noodle with chitosan had $1.76 \%$ cooking loss. These results were similar to Wandee et al. (2014) who found that the cooking loss in noodles containing fibers from the pomelo peel increased from 1.3 to $2.4 \%$. Similarly, Tiboonbun et al. (2011) also found that the noodles mixed with banana flour had cooking loss ranging between 1.0 and $2.5 \%$. In addition, Thomas et al. (2014) reported that the cooking loss in flat rice noodles was between 5.9 and $7.14 \%$. Since the CPL has a high ability to absorb water, the noodles with added CPL had less cooking time $(0.5 \mathrm{~min})$ than the other samples (1.5 min) as shown in Table 3. Regarding water absorption, the weights of the noodle with CPL was similar to the control samples, which was 24.99 and 24.87 g, respectively. Texture measurement showed that the tensile strength of the noodle with CPL was $22.61 \mathrm{~g}$. force, the tensile strength of the noodle with chitosan was 24.36 g.force, and the tensile strength of the noodle with thymol was 30.02 g.force. For the noodles with no additive and benzoic acid, their tensile strengths were 37.39 and 37.23 g.force, respectively. These are equivalent to general semi-dried rice noodles that were between 39 and 43 g.force (Cham and Suwannaporn, 2010). Similarly, Qazi et al. (2014) reported that the addition of sweet potato starch to general semi-dried rice noodles ranged between 18 and 43 g.force.

\section{Sensory properties of cooked noodles}

Hedonic scores of the developed noodle with different additives (0-day storage) are presented in Table 4. The hedonic score for appearance, aroma, taste, flavor, texture, and overall-liking of noodles with CPL were slightly like $(6.1,6.0,6.1,6.5,6.5$, and 6.0 , respectively). The noodle with thymol was unacceptable for consumers with the
(A)

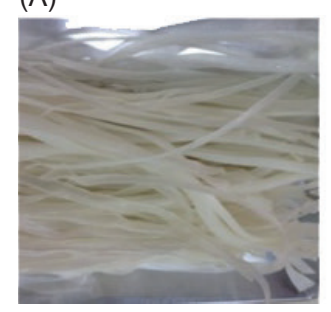

(B)

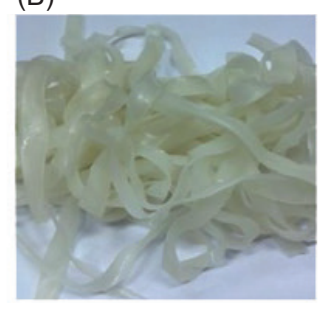

(C)

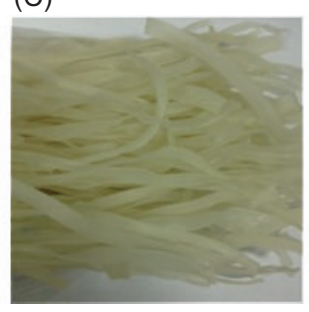

(D)

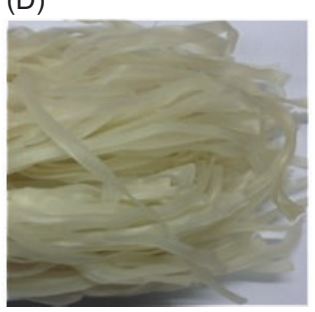

(E)

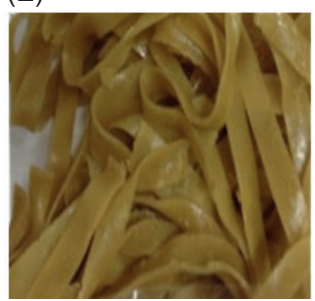

Figure 2. Characteristics of the noodles with different additives. (A) Control. (B) Benzoic acid. (C) Chitosan. (D) Thymol. (E) CPL. 
Table 3. Effect of different additives on the quality of the semi-dried rice noodles.

\begin{tabular}{|c|c|c|c|c|c|c|c|c|}
\hline Samples & $L^{\text {*ns }}$ & $a^{*}$ & $b^{*}$ & $\Delta \mathrm{E}^{*}$ & $\begin{array}{l}\text { Cooking } \\
\text { time (min) }\end{array}$ & $\begin{array}{c}\text { Cooking loss } \\
(\%)\end{array}$ & $\begin{array}{c}\text { Water } \\
\text { absorption (\%) }\end{array}$ & $\begin{array}{l}\text { Tensile strength } \\
\text { (g.force) }\end{array}$ \\
\hline Control & $68.2 \pm 0.4$ & $-1.8 \pm 0.1^{c}$ & $0.9 \pm 0.2^{d}$ & - & 1.5 & $0.98 \pm 0.01^{a}$ & $24.9 \pm 0.03^{c}$ & $37.4 \pm 0.5^{a}$ \\
\hline Benzoic acid & $65.5 \pm 0.4$ & $-1.8 \pm 0.1^{c b}$ & $3.4 \pm 0.1^{b}$ & 3.67 & 1.5 & $0.80 \pm 0.02^{\mathrm{a}}$ & $31.9 \pm 0.04^{a}$ & $37.2 \pm 0.5^{a}$ \\
\hline Chitosan & $67.6 \pm 0.2$ & $-1.7 \pm 0.1^{b}$ & $2.5 \pm 0.6^{c}$ & 1.68 & 1.5 & $1.76 \pm 0.01^{b}$ & $30.4 \pm 0.1^{b}$ & $24.4 \pm 0.5^{c}$ \\
\hline Thymol & $69.9 \pm 0.1$ & $-1.6 \pm 0.1^{b}$ & $3.9 \pm 0.1^{b}$ & 3.39 & 1.5 & $1.14 \pm 0.01^{c}$ & $33.5 \pm 0.03^{a}$ & $30.0 \pm 0.6^{b}$ \\
\hline CPL & $70.6 \pm 0.4$ & $1.1 \pm 0.1^{\mathrm{a}}$ & $17.5 \pm 0.3^{\mathrm{a}}$ & 16.7 & 0.5 & $4.69 \pm 0.12^{\mathrm{a}}$ & $25.0 \pm 0.01^{c}$ & $22.6 \pm 0.3^{d}$ \\
\hline
\end{tabular}

Values are the mean and standard deviation. Mean values in the same column with different letters are significantly different $(P<0.05)$. ${ }^{\text {ns }}$ indicates not significant $(P \geq 0.05)$. The cooking time was measured by sampling every $0.5 \mathrm{~min}$.

overall-liking score below 5 . This may be because of the strong flavor of thymol, resulting in an unpleasant smell and taste of the noodles.

\section{Microbiological quality evaluation of semi-dried rice noodles}

Based on food safety, microbial property is a major concern. Table 5 shows the result of total plate count during storage. For standard value, the total plate count must be no higher than $1 \times 10^{3} \mathrm{CFU} / \mathrm{g}$. It was found that the noodle with benzoic acid and CPL could be kept for
3 days while the noodle with thymol could be kept for only 2 days because total plate count exceeded the standard. Moreover, the total plate count of the control noodle (no additive) and noodle with chitosan was rejected after 1-day storage due to over standard value $\left(1 \times 10^{3}\right.$ $\mathrm{CFU} / \mathrm{g}$ ) for semi-dried noodle as mentioned by FDA. Considering the appearance of noodles with no mold that could be detected by the naked eye, the standard amount was set at no higher than $10 \mathrm{CFU} / \mathrm{g}$. The amount of yeasts and molds are shown in Table 6. The noodle with thymol could be kept for 6 days, while the noodle with benzoic acid and CPL could be kept only for 4 days.

Table 4. Hedonic score using 9-point scale of 50 consumers on cooked rice noodle with different additives.

\begin{tabular}{lccccc} 
Sensorial attributes & Control & Benzoic acid & Chitosan & Thymol & CPL \\
\hline Appearance & $7.8 \pm 0.8^{\mathrm{a}}$ & $6.5 \pm 1.0^{\mathrm{c}}$ & $7.0 \pm 0.8^{\mathrm{b}}$ & $6.5 \pm 1.0^{\mathrm{c}}$ & $6.1 \pm 1.3^{\mathrm{c}}$ \\
Aroma & $7.5 \pm 1.1^{\mathrm{a}}$ & $6.6 \pm 1.2^{\mathrm{b}}$ & $7.1 \pm 0.7^{\mathrm{a}}$ & $5.7 \pm 1.5^{\mathrm{c}}$ & $6.0 \pm 1.1^{\mathrm{c}}$ \\
Taste & $7.4 \pm 1.1^{\mathrm{a}}$ & $6.8 \pm 1.0^{\mathrm{b}}$ & $7.0 \pm 0.8^{\mathrm{ab}}$ & $3.6 \pm 1.5^{\mathrm{d}}$ & $6.1 \pm 1.5^{\mathrm{c}}$ \\
Flavor & $7.4 \pm 0.8^{\mathrm{a}}$ & $6.9 \pm 0.9^{\mathrm{a}}$ & $6.3 \pm 1.0^{\mathrm{b}}$ & $3.2 \pm 1.5^{\mathrm{d}}$ & $6.5 \pm 1.5^{\mathrm{c}}$ \\
Texture & $7.4 \pm 0.9^{\mathrm{a}}$ & $7.2 \pm 0.9^{\mathrm{a}}$ & $7.0 \pm 1.1^{\mathrm{a}}$ & $6.1 \pm 1.4^{\mathrm{b}}$ & $6.5 \pm 1.4^{\mathrm{c}}$ \\
Overall-liking & $7.7 \pm 0.9^{\mathrm{a}}$ & $7.5 \pm 1.0^{\mathrm{a}}$ & $7.3 \pm 0.9^{\mathrm{a}}$ & $4.2 \pm 1.5^{\mathrm{c}}$ & $6.0 \pm 0.8^{\mathrm{b}}$
\end{tabular}

Values are the mean and standard deviation. Mean values in the same row with different letters are significantly different $(P<0.05)$.

Table 5. Total plate count of semi-dried rice noodles with different additives during storage.

\begin{tabular}{|c|c|c|c|c|c|}
\hline \multirow[t]{2}{*}{ Storage (day) } & \multicolumn{4}{|c|}{ Total plate count (CFU/g) } & \multirow[b]{2}{*}{ CPL } \\
\hline & Control & Benzoic acid & Chitosan & Thymol & \\
\hline 0 & $2.9 \times 10^{2}$ & $1.2 \times 10$ & $2.9 \times 10^{2}$ & $1.0 \times 10^{2}$ & $1.1 \times 10$ \\
\hline 1 & $3.5 \times 10^{3}$ & $4.3 \times 10$ & $3.8 \times 10^{3}$ & $3.0 \times 10^{2}$ & $2.4 \times 10$ \\
\hline 2 & nd & $3.0 \times 10^{2}$ & nd & $\underline{6.0 \times 10^{2}}$ & $1.3 \times 10^{2}$ \\
\hline 3 & nd & $\underline{1.0 \times 10^{3}}$ & nd & $2.0 \times 10^{3}$ & $\underline{1.0 \times 10^{3}}$ \\
\hline 4 & nd & $1.0 \times 10^{5}$ & nd & nd & $3.0 \times 10^{8}$ \\
\hline 5 & nd & nd & nd & nd & nd \\
\hline 6 & nd & nd & nd & nd & nd \\
\hline
\end{tabular}

nd indicates that the samples were not determined due to molds in physical appearance.

The underline represents that the day that the total plate count were not higher than the standard amount set $\left(1 \times 10^{3} \mathrm{CFU} / \mathrm{g}\right)$. 
Table 6. Yeasts and molds of semi-dried rice noodles with different additives during storage.

\begin{tabular}{|c|c|c|c|c|c|}
\hline \multirow{2}{*}{$\begin{array}{l}\text { Storage } \\
\text { (day) }\end{array}$} & \multicolumn{5}{|c|}{ Amounts of yeasts and molds (CFU/g) } \\
\hline & Control & $\begin{array}{l}\text { Benzoic } \\
\text { acid }\end{array}$ & Chitosan & Thymol & CPL \\
\hline 0 & $<1.0$ & $<1.0$ & $<1.0$ & $<1.0$ & $<1.0$ \\
\hline 1 & $<1.0$ & $<1.0$ & $<1.0$ & $<1.0$ & $<1.0$ \\
\hline 2 & $\underline{5}$ & $<1.0$ & $\underline{8}$ & $<1.0$ & $<1.0$ \\
\hline 3 & 12 & $\underline{8}$ & 11 & $<1.0$ & $\underline{7}$ \\
\hline 4 & nd & 11 & nd & 3 & 14 \\
\hline 5 & nd & nd & nd & $\underline{7}$ & nd \\
\hline 6 & nd & nd & nd & 13 & nd \\
\hline \multicolumn{6}{|c|}{$\begin{array}{l}\text { nd indicates that the samples were not determined due to molds in } \\
\text { physical appearance. } \\
\text { The underline represents the day that yeasts and molds were not } \\
\text { higher than the standard amount set }(<10 \mathrm{CFU} / \mathrm{g}) \text {. }\end{array}$} \\
\hline
\end{tabular}

In addition, the control samples (no additive) and the noodles with chitosan were found to have a short shelflife since they could be kept only for 3 days. However, the deterioration of noodle that detect by total plate count occurred before the defect from yeast and molds. Therefore, the shelf-life of noodles was based on total plate count analysis.

\section{Conclusions}

Using 5\% of the pepsin enzyme to extract peptides from Lablab can be effective to inhibit the growth of B. cereus. However, it cannot inhibit the growth of $S$. aureus and E. coli. For application in noodles, adding CPL resulted in high yellowness and low cooking time, compared to other noodles. For shelf-life of noodles, $200 \mathrm{mg} / \mathrm{mL}$ CPL could be extended more than 3 times when compared to the control noodle (no additive), which could be kept only for 1 day. The CPL was nearly as effective as benzoic acid that could be kept for 3 days. Furthermore, hedonic score in overall-liking showed a slightly like (6.2) for the noodles with CPL. It is suggested that the CPL could be used as the new natural additive and seems to be promising to apply in food products. However, future work is required to do more in molecular purification, testing and another toxicity of the extracts for finding more mechanisms of its applications.

\section{Acknowledgements}

This research project is supported by TSRI. This present work was also financially supported by Thailand Research Fund (Grant No. MSD5610074) and Isariyaphon Limited Partnership.

\section{Conflict of Interest}

The authors declare no conflict of interest associated with this research.

\section{References}

AACC International, 2010. Approved methods of the American association of cereal chemistry. 11th ed. Methods 66-50. AACCI, St Paul, MN.

AOAC, 2007. Official methods of analysis of AOAC International. 18th ed. Methods 950.46, 976.06, 960.39, 942.05, 962.09, 994.12, 999.11, and 997.02. AOAC International, Gaithersburg, MD.

Arciola, C.R., Campoccia, D., Ravaioli, S. and Montanaro, L., 2019. Polysaccharide intercellular adhesion in biofilm: structural and regulatory aspects. Frontiers in Cellular and Infection Microbiology 5(7): 1-10. http://dx.doi.org/10.3389/ fcimb.2015.00007

Berthold-Pluta, A., Pluta, A., Garbowska, M. and Stefanska, I., 2019. Prevalence and toxicity characterization of Bacillus cereus in food products from Poland. Foods 8(7): 269-280. http://dx.doi. org/10.3390/foods 8070269

Borijindakul, L. and Phimolsiripol, Y., 2013. Physicochemical and functional properties of starch and germinated flours from Dolichos lablab. Food and Applied Bioscience Journal 1: 69-80. Retrieved from https://li01.tci-thaijo.org/index.php/fabjournal/ article/view/77360

Cantor, S., Vargas, L., Rojas-A, O.E., Yarce, C.J., Salamanca, C.H. and Onate-Garzon, J., 2019. Evaluation of the antimicrobial activity of cationic peptides loaded in surface-modified nanoliposomes against foodborne bacteria. International Journal of Molecular Science 20(3): 1-15. http://dx.doi.org/10.3390/ijms20030680

Cheison, S.C., Bor, E.K., Faraj, A.K. and Kulozik, U., 2012. Selective hydrolysis of $\alpha$-lactalbumin by acid protease A offers potential for $\beta$-lactoglobulin purification in whey proteins. LWT-Food Science Technology 49(1): 117-122. http://dx.doi.org/10.1016/j. lwt.2012.03.022

Cham, S. and Suwannaporn, P., 2010. Effect of hydrothermal treatment of rice flour on various rice noodles quality. Journal of Cereal Science 51(3): 284-291. http://dx.doi.org/10.1016/j.jcs.2010.01.002

Chung, H.J., Cho, A. and Lim, S.T., 2012. Effect of heat-moisture treatment for utilization of germinated brown rice in wheat noodle. LWT-Food Science Technology 47(2): 342-347. http:// dx.doi.org/10.1016/j.lwt.2012.01.029

Codex, 2009. General standard for food additives codex STAN 1921995. Food and Agriculture Organization of the United Nation, World Health Organization. Available at: http://www.fao.org/ gsfaonline/docs/CXS_192e.pdf

Dia, V.P., Bringe, N.A. and Mejia, E.G., 2014. Peptides in pepsinpancreatin hydrolysates from commercially available soy products that inhibit lipopolysaccharide-induced inflammation in macrophages. Food Chemistry 152(1): 423-431. http://dx.doi. org/10.1016/j.foodchem.2013.11.155

Duangmal, K. and Saetongtae, B., 2014. Protein modification using proteases and its applications. KKU Science Journal 42: 274-288. 
El-Araby, M.M., El-Shatoury, E.H., Soliman, M.M. and Shaaban, H.F., 2020. Characterization and antimicrobial activity of lectins purified from three Egyptian leguminous seeds. AMB Express 10: 90. http://dx.doi.org/10.1186/s13568-020-01024-4

Gasu, E.N., Ahor, H.S. and Borquaye, L.S., 2018. Peptide extract from Olivancillaria hiatula exhibits broad-spectrum antibacterial activity. BioMed Research International 2018: 1-11. http:// dx.doi.org/10.1155/2018/6010572

Guinane, C.M., Kent, R.M., Norberg, S., O’Connor, P.M., Cotter, P.D., Hill, C., et al. 2015. Generation of the antimicrobial peptide caseicin A from casein by hydrolysis with thermolysin enzymes. International Dairy Journal 49: 1-7. http://dx.doi. org/10.1016/j.idairyj.2015.04.001

Hossain, S., Ahmed, R., Bhowmick, S., Mamun, A.A. and Hashimoto, M., 2016. Proximate composition and fatty acid analysis of Lablab purpureus (L.) legume seed; implicates to both protein and essential fatty acid supplementation. SpringerPlus 5: 1-10. http://dx.doi.org/10.1186/s40064-016-3587-1

Inetianbor, J.E., Yakubu, J.M. and Ezeonu, S.C., 2015. Effects of food additives and preservatives on man- A review. Asian Journal of Science and Technology 6(2): 1118-1135.

Intorasoot, S., 2013. Antimicrobial peptides: the natural proteins and the future application for treatment of infectious diseases. Bulletin Chiang Mai Associated Medical Sciences 46(1): 1-19.

Jaisankar, P. and Manivannan, K., 2018. Effect of different levels of nitrogen and phosphorus on growth and yield characters of bush bean (Dolichos lablab var. typicus). Plant Archives 18(2): 2194-2198. Available at: http://www.plantarchives.org/1802/2194-2198\%20(4275).pdf

Kala, B.K., Soris, P.T., Mohan, V.R. and Vadivel, V., 2010. Nutrient and chemical evaluation of raw seed of five varieties of Lablab purpureus (L.) sweet. Advances in Bioresearch 1(1): 44-53. Available at: http://www.soeagra.com/abr/vol1/44-53.pdf

Kuipers, A., Stapels, D.A.C., Weerwind, L.T., Ko, Y.P., Ruyken, M., Lee, J.C., et al. 2016. The Staphylococcus aureus polysaccharide capsule and $\mathrm{Efb}$-dependent fibrinogen shield act in concert to protect against phagocytosis. Microbiology 162(7): 1185-1194. http://dx.doi.org/10.1099/mic.0.000293

Laokuldilok, T., Potivas, T., Kanha, N., Surawang, S., Seesuriyachan, P., Wangtueai, S., et al. 2017. Physicochemical, antioxidant, and antimicrobial properties of chitooligosaccharides produced using three different enzyme treatments. Food Bioscience 18: 28-33. http://dx.doi.org/10.1016/j. fbio.2017.03.004

Lei, J., Sun, L., Huang, S., Zhu, C., Li, P., He, J., et al. 2019. The antimicrobial peptides and their potential clinical applications. American Journal of Translational Research 11(7): 3919-3931. Available at: https://www.ncbi.nlm.nih.gov/pmc/articles/ PMC6684887/.

Li, M., Zhu, K.X., Guo, X.N., Brijs, K. and Zhou, H.M., 2014. Natural additives in wheat-based pasta and noodle products: opportunities for enhanced nutritional and functional properties. Comprehensive Reviews in Food Science and Food Safety 13(4): 347-357. http://dx.doi.org/10.1111/1541-4337.12066

Liu, Y.F., Chaiwanichsiri, S. and Laohasongkram, K., 2014. Physicochemical properties of flour recovered from broken rice noodles during production. International Journal of Food Science and Technology 49(7): 1722-1728. http://dx.doi. org/10.1111/ijfs.12481

Ministry of Public Health, 2016. Notification of the Ministry of Public Health (No. 381) B.E 2559 (2016) Re: Food Additives (No.4). Bangkok, Thailand. Available at: http://www.fda.moph. go.th/sites/food/FoodAdditives/MOPH(No.381)B.E.2559(2016) Re_AdditiveNo.4.pdf.

Mirzapour-Kouhdasht, A., Moosavi-Nasab, M., Kim, Y.-M. and Eun, J.-B., 2020. Antioxidant mechanism, antibacterial activity, and functional characterization of peptide fractions obtained from barred mackerel gelatin with a focus on application in carbonated beverages. Food Chemistry 342: 128339. http://dx.doi. org/10.1016/j.foodchem.2020.128339

Patel, H., Vaghasiya, Y., Vyas, B.R.M. and Chanda, S., 2012. Antibiotic-resistant Staphylococcus aureus: a challenge to researchers and clinicians. Bacteriology Journal 2(2): 23-45. http://doi.org/10.3923/bj.2012.23.45

Phimolsiripol, Y., Siripatrawan, U., Teekachunhatean, S., Wangtueai, S., Seesuriyachan, P., Surawang, S., et al. 2017. Technological properties, in vitro starch digestibility and in vivo glycaemic index of bread containing crude malva nut gum. International Journal of Food Science and Technology 52(4): 1035-1041. http://dx.doi.org/10.1111/ijfs.13369

Qazi, I.M., Rakshit, S.K., Tran, T., Javidullah and Khan, M.Z., 2014. Effect of blending selected tropical starches with rice flour on the cooking quality and texture of rice based noodles. Sarhad Journal of Agriculture 30(2): 257-263.

Rahman, S.A. and Akhter, S.M., 2018. Antibacterial and cytotoxic activity of seeds of white hyacinth bean (Lablab purpureus L. sweet "white"). Journal of Advanced Biotechnology and Experimental Therapeutics 1(2): 49-54. http://doi.org/10.5455/ jabet.2018.d9

Ramos, Y., Gonzalez, A., Sosa-Acosta, P., Perez-Rivrsol, Y., Garcia, Y., Castellanos-Serra, L., et al. 2019. Sodium dodecyl sulfate free gel electrophoresis/electroelution sorting for peptide fractionation. Journal of Separation Science 42: 3712-3717. http://dx.doi.org/10.1002/jssc.201900495

Ratnayani, K., Panjaitan, I.W.S. and Puspawati, N.M., 2017. Screening potential antioxidant and antimicrobial activities of protein hydrolysates derived from germinated lablab bean, pigeon pea and kidney bean. Journal of Health Sciences and Medicine 1(1): 24-27. http://dx.doi.org/10.24843/JHSM.2017.v01.i01.p07

Reshmi, S.K, Aravinthan, K.M. and Devi, P.S., 2012. Antimicrobial activity of Basella alba fruit. International Journal of Pharmaceutical Sciences and Research 3(12): 4757-4761. http:// dx.doi.org/10.13040/IJPSR.0975-8232.3(12).4757-61

Saha, R.K., Tuhin, S.H.M., Jahan, N., Roy, A. and Roy, P., 2014. Antibacterial and antioxidant activities of a food lectin isolated from the seeds of Lablab purpureous. American Journal of Ethnomedicine 1(1): 8-17.

Saikhunthod, M. and Peerapattana, P., 2015. Wastes reduction in production process using green productivity: a case study in rice noodle factory. Journal of Applied Science 14(2): 40-57.

Sukamto, M., Sudiyono, S., Galih, P.D. and Karim, F., 2019. Effects of pepsin on the separation of the globulin $7 \mathrm{~s}$ and $11 \mathrm{~s}$ fraction from 
Lablab bean (Komak) seeds (Dolichos lablab) and its functional properties. Pakistan Journal of Nutrition 18(8): 783-790. http:// dx.doi.org/10.3923/pjn.2019.783.790

Surin, S., Seesuriyachan, P., Thakeow, P., You, S.G. and Phimolsiripol, Y., 2018. Antioxidant and antimicrobial properties of polysaccharides from rice brans. Chiang Mai Journal of Science 45: 1372-1382.

Thomas, R., Yeoh, T.K., Wan-Nadiah, W.A. and Rajeev, B., 2014. Quality evaluation of flat rice noodles (Kway Teow) prepared from Bario and Basmati rice. Sains Malaysiana 43(3): 339-347.

Tiboonbun, W., Sungsri-in, M. and Moongngarm, A., 2011. Effect of replacement of unripe banana flour for rice flour on physical properties and resistant starch content of rice noodle. International Journal of Biological, Biomolecular, Agricultural, Food and Biotechnological Engineering 5: 558-5561. http://dx. doi.org/10.5281/zenodo.1083547

Tsutsumi, R. and Tsutsumi, Y.M., 2014. Peptides and proteins in whey and their benefits for human health. Austin Journal of Nutrition and Food Science 1(1): 1-9.

Vipra, A., Desai, N.S., Junjappa, P.R., Roy, P., Poonacha, N., Ravinder, P., et al. 2013. Determining the minimum inhibitory concentration of bacteriophages: Potential advantages. Advances in Microbiology 3(2): 181-190. http://dx.doi. org/10.4236/aim.2013.32028

Wandee, Y., Uttapap, D., Puncha-arnon, S., Puttanlek, C., Rungsardthong, V. and Wetprasit, N., 2014. Enrichment of rice noodles with fibre-rich fractions derived from cassava pulp and pomelo peel. International Journal of Food Science and Technology 49(1): 2348-2355. http://dx.doi.org/10.1111/ ijfs. 12554
Wang, X., Ma, Z., Li, X., Liu, L., Yin, X., Zhang, K., et al. 2018. Food additives and technologies used in Chinese traditional staple foods. Chemical and Biological Technology in Agriculture 5: 1. http://dx.doi.org/10.1186/s40538-017-0113-9

Wang, J. and Vermerris, W., 2016. Antimicrobial nanomaterials derived from natural products. Materials 9(4): 1-19. http://dx. doi.org/10.3390/ma9040255

Wang, J., Zhao, M., Zhao, Q. and Jiang, Y., 2007. Antioxidant properties of papain hydrolysates of wheat gluten in different oxidation systems. Food Chemistry 101(4): 1658-1663. http://dx.doi. org/10.1016/j.foodchem.2006.04.024

Wangtueai, S., Phimolsiripol, Y., Vichasilp, C., Regenstein, J.M. and Schoenlechner, R., 2020. Optimization of gluten-free functional noodles formulation enriched with fish gelatin hydrolysates. LWT- Food Science and Technology 133: 109977. http://dx.doi. org/10.1016/j.lwt.2020.109977

Wong, J.H. and Ng, T.B., 2005. Lunatusin, a trysin-stable antimicrobial peptide from Lima beans (Phaseolus lunatus L.). Peptides 26(11): 2086-2092. http://dx.doi.org/10.1016/j. peptides.2005.03.004

Zhang, X.P., Li, X.J., Yang, M.J., Yang, X. and Zhao, X., 2020. Effect of antioxidant extracted from bamboo leaves on the quality of box-packaged sturgeon fillets stored at $4{ }^{\circ} \mathrm{C}$. Quality Assurance and Safety of Crops and Foods 12(2): 73-80. http://dx.doi. org/10.15586/qas.v12i2.690

Zhang, Z., Feng, L., Xu, H., Liu, C., Shah, N.P. and Wei, H., 2016. Detection of viable enterotoxin-producing Bacillus cereus and analysis of toxigenicity from ready-to-eat foods and infant formula milk powder by multiplex PCR. Journal of Dairy Science 99(2): 1047-1055. http://doi.org/10.3168/jds.2015 